Graeco-Latina Brunensia $25 / 2020 / 2$

https://doi.org/10.5817/GLB2020-2-13

Benedict of Canfield (2020). The Rule of Perfection / 3. Translated and published by Ladislav Tkáčik and Erika Juríková. (333p.). Kraków: Towarzystwo Słowaków w Polsce 2020. ISBN 978-80-89739-18-9.

\title{
Rastislav Nemec
}

The Rule of Perfection (Regula perfectionis) written by Benet Canfield (1611) from the literary perspective represents a real gem of spiritual literature whose inner wealth and spiritual contribution can be nowadays hard to describe historically and it is even harder to trace it. Despite many historical circumstances which prevented this work to come to the scene of literature, shortly after its origination it was published 18 times in the period of several decades itself, and within the century its authorized Latin edition was published eight times, five times it was published in German and Flemish and after 1610 even in Arabic.

This masterpiece being present in the libraries of well-known giants, spiritual and political authorities, travelling across the borders of religions and cultures in the times of turbulent (and even religious) wars perfectly depicts the timeless and supranational vertical line of spiritual revival, which was the real antipodal point of political fights, and in the French, as well as the European area it restored new spiritual culture and millieu dévot - the way of reformed devotion as the only solution for a continent that was falling apart.

This work was published thanks to the support of the Arts Support Fund of the Slovak Republic. We can experience it in form of a professional and erudite translation by associate professors Erika Juríková and Ladislav Tkáčik. After a thorough review of this translation, we can more realistically imagine how difficult the work on translation was due to the semantic or etymological dilemmas. They tried to clarify these and similar ones in a rather extensive in- troductory study in which they describe the life of Benet Canfield and they show the topics of his work and outline the itinerary of author's further writing. In the introductory study (p. 11 - 39) they explain very well the circumstances of the era, that means the theological and spiritual background of writing similar mystic works and comment in details on some specifications of contemplations in the context of Capuchin spirituality mentioned by Benet. The introductory study contains erudite notes with (not only) extensive references to contemporary and modern literature.

Translation of this work was difficult not only because of linguistic nuances (which the authors have handled really well), but we can appreciate the translation of this work more if we realize the limits of a language the applicability of which ends in certain point in case of mystic experience (similar to the role of intellect and its functions). From the professional point of view, the authors of the translation showed a great extent of knowledge and orientation in contemporary and well as historical texts (Bonaventure, his Reductio artium in theologiam, De scientia Christi or Pseudo-Dionysius the Areopagite, Augustine of Hippo and his De vera religione), which were basis of this work, as well as contemporary lecture and interpretation of the Bible (with its originating historical and critical translation), in contemporary works of spiritual authorities (Renaissance and Spanish mystics), or finally in the spiritual background of Franciscan and Capuchin texts (the revival and return to hermit elements of spirituality this work portrays). 
Translation of this interesting Latin text was made based on the Nuremberg issue of the work in 1741 published under the name Regula perfectionis, continens Breve E lucidum compendium totius vitae spiritualis... Due to the origin as well as containing the historical patina of the work (logotype/double letter, majuscule, contemporary punctuation) the translation required a lot of editing in order for the work to be reader-friendly, which the authors managed well. Benet's literary language in the original and in the translation is full of significant tunefulness a figurativeness, which is a proof of the authors' considerable knowledge of historical and contemporary literature. This has put higher demands in handling semantic nuances and sometimes even the authors of the publication had to decide pragmatically and choose a preferred and especially clear term.

The greatest challenge or the translators of Benet's Rule was not only understanding and correct interpretation of the difficult renaissance text but also understanding and expression of the meaning of philosophical and theological terms. As an example in this outstanding translation, it is worth mentioning a term that can be understood based on the description but it is hard to clearly find a term that covers complete meaning and it would depict the French word "anéantissement" or its English equivalent "annihilation" (the Latin origin annihilatio has its form rather as a verb in active and in passive - "ad-nihil" - fr. anéantir). This term translated as "zničotňovanie", creates an important framework in this work the idea of which is clarified in the work when the reader discovers how meaningfully it creates basis for the whole and uncovers the purpose of the text. And it represents the figural typological kenosis, which is the objective of mystic progress (Christ/ Christian) - in Slovak language, however this term has no proper equivalent. The authors of the translation used their professional abilities and knowledge of similar works - for example, the mystic work of Marguerite de Porrette, where we can find this term in his work Le Miroir des Ames simples - and they have handled the term extremely well because they did not ballast it with any contemporary or present-day misleading nuances. There are more similar examples which can be appreciated from the translation point of view.

The work is published in Latin edition with mirror-view Slovak translation. It can be recommended as a high-quality and valuable piece and from the perspective of current translation literature it can be assessed as really breakthrough. Works of similar spiritual depth and topic in relevant form with corresponding Latin text, introductory study and professional and creative translation while maintaining the feeling of historical patina of the language can be unfortunately found very sporadically.

prof. PhDr. Rastislav Nemec, PhD. / rastislav.nemec@truni.sk

Department of Christian Philosophy

Trnava University in Trnava, Faculty of Theology

Hornopotočná 23, 91843 Trnava, Slovak Republic 